\title{
External funding of major capital projects in the UK Higher Education sector: issues of demand, supply and market timing?
}

\author{
Laura McCann ${ }^{1}$, Norman Hutchison ${ }^{1}$, Alastair Adair ${ }^{2}$ \\ ${ }^{1}$ University of Aberdeen Business School, Aberdeen, Scotland. UK \\ ${ }^{2}$ Ulster University, Belfast, Northern Ireland. UK
}

\begin{abstract}
The aim of this paper is to consider the sources of finance used to support major capital expenditure in the UK Higher Education sector and to reflect on any differences between traditional corporate finance theory and practice in the UK university sector. Utilising both HESA data returns and published annual accounts, an in-depth analysis using a logit structure is carried out on data from the top 63 UK universities over the period 2014 to 2017, to establish the range of funding sources adopted for major capital projects, all set within the context of the UK macro environment and a period of low interest rates. The research also carries out a survey of funders to understand the decision criteria used by lenders active in the Higher Education sector and a survey of university finance directors to determine the use of the funds, the reasons behind past lending decisions and to ascertain likely future demand for finance to fund major capital projects.
\end{abstract}

Key words: university funding, debt sourcing, bond finance, private placements. 


\section{Introduction}

In 1988 the Teaching and Higher Education Act introduced tuition fees in all the countries of the United Kingdom. However, as result of the establishment of devolved national administrations for Scotland, Wales and Northern Ireland, different fee arrangements now exist in each country. For example, in England tuition fees for UK and EU students are capped at $£ 9,250$ p.a., while in Northern Ireland the fees are limited to $£ 4,030$ p.a. Welsh students can be charged up to $£ 9,000$ p.a. in tuition fees by universities and colleges in Wales but means-tested maintenance grants and tuition fee loans are available. In Scotland, universities are not allowed to charge fees to Scottish based or EU students, but instead received funding from the Scottish government, which varies by subject, but averages around $£ 5,000$ p.a. per student. This funding model has introduced significant differences in the financial strength of the universities both between and within countries and has been subject to considerable criticism from all stakeholders, with alternative funding options being promoted by the Labour and Liberal Democrat parties. For example, Universities Scotland estimated that in comparison to English universities, Scottish universities face a funding gap of approximately $£ 202 \mathrm{~m}$ per year in comparison to English universities, providing English universities with a comparative advantage in being able to attract the best students and academic staff.

This differential funding model exists at a time when the UK government has allowed an increase in supply of student places. The removal of the cap on the number of students that can be recruited by universities in England and Wales, introduced in 2015/16, has significantly increased the competitive nature of the market to attract both UK and international students ${ }^{1}$. Moreover, competition to recruit UK nationals is likely to intensify in a post Brexit environment, if demand from EU students declines. In Scotland the post Brexit scenario is particularly challenging given that the Scottish government currently pays the undergraduate fees of EU nationals studying in Scotland.

This competitive market has resulted in significant capital investment by a number of universities on major building works to maintain and grow student numbers, with state-of-the-art teaching space, halls of residence, student union buildings and sport facilities being constructed. While some of the funding has been supported by the rise in tuition fee income, universities have also used a range of funding options from private bond issuance to commercial bank lending, both short term and long term, and loans from the European Investment Bank to finance the expenditure.

Adopting a corporate finance theory perspective, the aim of this paper is to consider the sources of finance used to support major capital expenditure in the UK Higher Education sector. Using a sample of the top 63 UK universities and a survey of 27 finance directors of UK universities, we consider what types of university are borrowing to fund major capital projects and distinguish between the different funding options that universities have access.

The remainder of this paper is structured as follows. Section 2 outlines the characteristics of UK Higher Education funding and looks at some of the structural and financial challenges that lie ahead. Section 3 reviews the literature on commercial property and corporate lending while the research design is

\footnotetext{
${ }^{1}$ The cap on student numbers has been rising for several years. In 2013 it was announced that in September 2014 , the cap on student numbers would increase by 30,000 students and that from September 2015-16 that there would be no cap on student numbers in England and Wales. The student cap remains in place in Scotland and Northern Ireland for local students.
} 
discussed in detail in Section 4. Section 5 analyses the data and discusses the interview findings and survey results, while Section 6 critiques three mini case studies. Section 6 provides a summary and presents conclusions from the research.

\section{UK University Funding}

UK universities do not have a coherent system of funding. Universities in the United Kingdom have generally been instituted by Royal Charter, Papal Bull, Act of Parliament or an instrument of government or the under the Further and Higher Education Act 1992. Greenaway and Haynes (2003) argue that UK higher education provision has been subject to profound changes over the past three decades comprising inter alia changes in overall participation, a dramatic decline in public funding, escalating staff: student ratios and a deteriorating infrastructure. Prior to 1998, universities were funded mainly by government but Greenaway and Haynes (2003) suggested that additional investment was required with estimates of the 'funding gap' in 2003 varying from $£ 1$ to $f 3$ billion per annum. As a result of this funding gap, additional resource has been required from non-government sources and universities have sought to bridge the 'funding gap' by increasing their private capital.

Goodman (2003) asked the question of where the resources were to be found to meet the demand, and whether universities could really grow their research impact with slow to limited growth in funding and no ability to control/set tuition fees. The solution proposed by Goodman was a revised business model to explore efficiency and effectiveness issues through cost reductions, changes in teaching models and new capital financing models based on public-private partnerships and direct borrowing.

\section{Generating external finance}

Universities are able to generate external finance through various sources. Funding councils established under the Further and Higher Education Act 1992 provided direct support to universities supplemented by tuition fees paid by students ${ }^{2}$. Universities are also able to generate income through endowment trust funds accumulated over generations of donations and investment. However, in this paper, we will be focusing on university borrowing from traditional debt sources namely banks, public bonds and privately placed bonds.

As far as we are aware, up until now there has been little academic research examining the debt source choice for universities. Cohen (1993) examined financing of student housing in the late 1980s and early 1990s where universities, in order to accommodate increasing student numbers, embarked on major site acquisition and building programmes both on and off campus. The overall funding requirement was estimated at over $f 1$ billion. At that time many banks and building societies were cautious about entering this market due to their unfamiliarity with the sector, however some major mortgage lenders familiar with the educational sector and university lending had developed innovative funding techniques, such as privately financed student residences.

\footnotetext{
${ }^{2}$ The funding councils have been replaced by the Office for Students in 2018. In a similar vein funding for university research was formerly provided by seven Research Councils which have now been incorporated within UK Research and Innovation together with Innovate UK and a new organisation Research England in 2018.
} 
Cohen outlined three principal methods as alternatives to the University extending its existing conventional banking facilities comprising finance leasing, conventional long-term mortgage finance and the then Business Expansion Scheme operating in the early 1990s (Harrison and Mason, 1989).

Many lenders viewed student accommodation as being too specialised with limited alternative use in the event of default. In order to reduce default risk universities developed new buildings in a way that they could be readily converted back to flats or houses suitable for private domestic use both in response to financier's demands and student preferences for self-contained flats and ensuite private rooms in smaller more user-friendly buildings.

\section{The changing context of UK Higher Education and international influences}

The UK Higher Education system is regarded as a global success story with the international diversity across the academic community a reflection of the quality and reputation of the sector and the depth of worldwide engagement over many years (Universities UK, 2018). In addition, as economic drivers, universities with their common focus on teaching, learning and innovation are at the heart of the new knowledge economy. Through their civic mission, they are well-placed to bring together ideas and improve systems and processes for the benefit of the sector and society as a whole (Beech et al, 2018).

Yet, despite such high regard, university education in England (and by inference in the other UK devolved administrations) has been subject to near constant reform over the past two decades (Belfield et al, 2017). While the trebling of tuition fees to $f 9,000$ in 2012 (now $f 9,250$ ) is regarded as the most significant of these reforms, there are a number of challenges now facing the sector relating to increased competition for local and overseas students, student loans, differential funding regimes in the devolved administrations, student mobility, and an increasing clamour for clarity of the role of universities, and whether they are they fit for purpose and provide value for money. Such issues are amplified by headlines regarding job losses, falling applications, uncertainty due to Brexit and financial pressures affecting the sector (Wales Online, 2019).

\section{New Regulatory Environment (England)}

Concerning the credit worthiness of universities, the Office for Students (OfS), acting as the regulator for Higher Education in England, has warned that universities are not too big to fail and they won't be bailed out in the event of a financial crisis. The regulator has likened universities to overconfident banks before the global financial crisis, where a lack of financial discipline can lead to poor decisionmaking which is inconsistent with the principle of autonomy and not in the interests of students (The Guardian, 2018). His comments were in response to reports of some universities facing cashflow pressures created by falling student numbers and the threat of lower student fees resulting from the Augar Review of student finance in England.

Nevertheless, others take a contrary view that it is doubtful that a mainstream university would be allowed to fail as a result of changes in government policy related to student fees, student visas or Brexit as the resulting political fallout is likely to be too great for government to allow this to happen. In this context, the Universities and Colleges Union (UCU) argue that universities are major employers in their locations so the impact on the local economy and employment opportunities would be too great to allow a university to fail. Rather UCU emphasise you don't protect student interests by allowing a university to fail. 


\section{Student Numbers}

Comparison of the number of UK higher education institutions (HEIs), in receipt of public funding over the decade from 2007-08 shows little change as shown in Table 1. According to Universities UK (2008a), using Higher Education Statistical Agency (HESA) data, there were $166 \mathrm{HEls}$ in 2007-08 ${ }^{3}$. In 2016-17 there were 2.32 million students studying at UK HEls. While the number of UK students has declined by $5 \%$ over the decade, there has been significant growth of $20 \%$ in EU students and especially non-EU international students which have increased by one third providing universities with enhanced tuition fee income.

Insert Table 1 about here

\section{Higher Education Finance}

Finance data for UK higher education providers in 2016/17, reveals a total income for the sector of $£ 34.7$ billion (HESA, 2018). Total income from tuition fees was $£ 17.7$ billion across the UK. Tuition fees represented $52.2 \%$ of total income in England and $55.9 \%$ in Wales. Following the Diamond Review (Welsh Government, 2016), student fees in Wales are now supported by means-tested maintenance grants and tuition fee loans. In Scotland and Northern Ireland funding body grants exceeded tuition fee income. While teaching grants in England have been replaced by student fees, the differential impact across the UK is large with Scotland and Northern Ireland consistently lagging behind England in terms of average funding per student for teaching as illustrated by Figure 1.

\section{Insert Figure 1 about here}

The combination of high fees and large maintenance loans contributes to English graduates having the highest student debts in the developed world. The 2015 policy that replaced maintenance grants with loans, means students from the poorest backgrounds will accrue debts of $£ 57,000$ (including interest) from a three-year degree. Their 'cash in pockets' has been protected, but now it is almost entirely in loans rather than free cash (Belfield, 2017). In order to reduce the debt burden, the House of Commons argues that Government should reinstate the means tested system of loans and maintenance grants (Parliament, 2018).

Student loans became a political issue in the 2017 UK general election when the Labour Party campaigned on a promise to abolish student fees. The resulting dramatic rise in votes for Labour from young people was met by a response from the Conservative Party in setting up the Augar Review into student loans which is due to report in early 2019. It is anticipated that student fees will be reduced from $£ 9,250$ to circa $£ 6,500$, a prospect that has been met by some Vice-Chancellors fearing such a reduction in income will have a huge detrimental impact of their ability to service existing debt commitments.

\section{Repayment of student loans}

A further political impact occurred in recognition that a significant proportion of student loans will never be repaid. In December 2018, the Government announced that it would change the way student

\footnotetext{
${ }^{3}$ While UUK quote a figure of 162 HEls in 2016-17 the summation of their figures for all four UK devolved administrations indicate a figure of 166.
} 
loans are charged to the national accounts (Public Finance, 2018). A portion of the government's student loan payment will be treated as capital spending rather than government lending from autumn 2019 which will increase the national deficit by $f 12 \mathrm{bn}$. In effect, the government is cancelling at issuance a portion of the loan that is not expected to be repaid (Public Finance, 2018). Public Finance infer that this will become a significant political issue impacting fiscal planning by potentially adding circa $f 72 \mathrm{bn}$ to the government's borrowing figures over the next five years and wiping out the $f 74 \mathrm{bn}$ fiscal windfall announced by the Chancellor in the 2018 budget.

Furthermore, the Higher Education Policy think-tank claim that the impact of this change represents a "triple whammy of fewer university places, less funding per student and tougher student loan repayments" (Public Finance 2018). The debate on student fees continues with the University and College Union (UCU) arguing that a new approach is needed that recognises that higher education is a public good and should be funded through taxation, including an increased contribution from business (Public Finance, 2018).

\section{International students}

The very significant growth in international (non-EU) students is matched by a dramatic increase of $160 \%$ in income from $f 1,800$ million to $f 4,683$ million over the decade as presented in Table 1 . The bulk of this income has been earned by Higher Education Institutions (HEIs) in England in contrast to the other three devolved administrations. The impact of international students on the UK economy is highly significant contributing $£ 25.8 \mathrm{bn}$ in $2014-15$ with Scotland contributing $£ 837 \mathrm{~m}$, Wales $£ 576 \mathrm{~m}$ and Northern Ireland $1123 \mathrm{~m}$ sharing a much smaller proportion than England.

\section{Value for money}

The House of Commons Education Committee addressed the issue of value for money in higher education and concluded that too many universities are not providing value for money and that students are not getting good outcomes from the degrees for which so many of them accumulate debt. Too many institutions are neither meeting skills needs nor providing the means for the socially disadvantaged to climb the ladder of opportunity (Parliament, 2018).

It is argued that the higher education system needs to have a much sharper focus on developing skills through for instance degree apprenticeships. The report calls for universities to be more transparent about graduate prospects, in terms of both earnings and destinations.

The value for money issue was again raised in The Times (2019a) on $2^{\text {nd }}$ January reporting a YouGov poll of 1,660 adults, two-thirds of whom believe that university tuition fees of $£ 9,250$ p.a. provide poor value for money. Such a finding adds momentum for calls to overhaul student funding.

\section{Unconditional offers}

Increasing competition for students and the income stream they generate is reflected in the steep increase in unconditional offers made to students rising dramatically from 2\% in 2013 to $32 \%$ in 2018, reflecting the need to fill places and increase teaching income. The report calls for the Office for Students to clamp down on their use, warning that their practice threatens to be detrimental to the interests of students and to undermine the higher education system (Parliament, 2018). 
Competition for students also emerges in the current debate regarding the dramatic increase in the award of first-class degrees by UK universities growing from 8\% 20 years ago to $27 \%$ in 2018 and has been questioned by the Office for Students (The Times, 2019b). The research shows that some universities were awarding first-class degrees to more than half of graduates and that the rationale for three-quarters of such degree awards is unexplained. There are calls for greater clarity on how universities convert degree marks into firsts, to restore credibility in what is seen as rampant grade inflation where institutions are manipulating algorithms to boost their performance and thereby attract students.

The Higher Education Policy Institute working with PWC (Beech, 2018) identify three strategic challenges in the current political climate namely increasing internationalisation, disruption caused by new technologies and the need for robust strategies and roadmaps.

\section{Internationalisation}

Internationalisation is a core component of UK higher education generating additional income from international ventures, enhancing diversity that overseas students bring to the campuses and facilitating the attraction and retention of overseas talent through international collaborations.

The significant growth in income from international students has been outlined above. Beech (2018) exposes the scale of cross subsidies in UK universities and finds each international student contributes on average $f 8,000$ to research from the university fees. However, to be successful in the international arena requires considerable investment and can expose higher education institutions to financial, legal and reputational risks. The rewards are significant as international students bring $£ 20.3$ billion net benefits to the UK economy which is felt right across the UK for example Sheffield Central $f 226 \mathrm{~m}$, Cardiff Central $£ 151 \mathrm{~m}$, Glasgow Central $£ 135 \mathrm{~m}$ and Belfast South $£ 29 \mathrm{~m}$.

\section{New Technologies}

Disruptive technologies and changes to educational delivery, referred to as the Fourth Industrial Revolution, is changing how universities are operating and how they manage information and collect data. Advantages include a greater agility, more collaborative learning, maximising new opportunities on Transnational Education (TNE) and enhancing the student experience.

Beech (2018) reports that such technological improvements have led to improved retention rates and lower costs at a global level. In the US, technology enhanced learning has produced better student outcomes in $72 \%$ of projects and average savings of $31 \%$. Student dropout rates have reduced from $18 \%$ to $12 \%$ via learning analytics in the University of New England, Australia. In the UK, $81 \%$ of first year students at Nottingham Trent University increased study time after seeing their own engagement data.

\section{Robust strategies and roadmaps}

Such disruptive technologies and change management are not without risks. Beech (2018) argues that universities and colleges must find people who are committed to positive change if they are to drive frontiers of technology forward for the benefit of the whole sector. Looking to the future Beech (2019) notes that the demand for higher education in $\mathbf{2 0 3 0}$ will in England see universities take on at least 
300,000 additional full-time undergraduate places. While this is good news in the long term, the scale of transformation required in the short-term of increasing capacity is substantial.

Improvements to university estates show that universities are planning for the longer-term. However, the short-term reduction in student numbers and increasing competition for international students is expected to increase competition sharply over the coming years especially if it becomes more common for students to switch providers under the new regulatory environment of the Office for Students. The risk is that a reduction in student numbers in the short-term and adverse impacts on underused facilities will create further challenges in the years ahead.

The Times (2019c) reports that five universities, including Southampton, UCL and Imperial College London, have more than doubled their borrowing in the past year to compete in the ever-tougher battle to attract more students from home and abroad. Consequently, a number of universities have been warned that they are on the brink of a "credit crunch" after embarking on a record borrowing spree despite deep uncertainty over their financial future. The sector's debts have risen over the past year to $f 10.8$ billion, three times more than before the financial crash.

The university campus of the future: an international perspective

It is not only UK universities who are in the process of campus redevelopment and many lessons can be learned from non-UK universities when planning redevelopment for future generations. In 2008, the Cornell University board of trustees approved an impressive master plan for the Ithaca campus which is to be developed over a 30-60 year time frame. The plan comprises five fundamental principles ranging from promoting academic mission (facilities for teaching and research), stewardship (protecting the physical environment - dual town and country - surrounding the campus), campus experience (facilities for social and cultural interaction), reinforcing the community and ensuring an integrative planning design. One of the most astounding aspects of the campus redevelopment plan included a number of 'green' eco-friendly initiatives which have been designed to satisfy campus requirements. For example, the university uses the on-campus Cayuga Lake to air condition campus buildings via a lake source cooling project and $15 \%$ of campus electrical needs have been fulfilled by the implementation of a new gas-fired heat and power facility.

Similarly, Curtin University in Perth, Australia, are in the process of their 20 year Greater Curtin campus development programme which they view as a fundamental part of positioning the university for future success as it builds on it's increase in world rankings. The Greater Curtin campus development programme aims to transform the main Bentley campus which lies $6 \mathrm{~km}$ from Perth Central Business District and create a community which resonates a mini city by means of increased student accommodation and retail opportunities.

In considering how major capital projects have been financed mention also needs to be made on the disruptive forces which are challenging the traditional delivery of higher education and consequently the type and size of space that is required. Recent years have seen the rise of the 'flipped classroom' with less demand for large lecture theatres and more requirements for interactive learning space and use of the virtual learning environment. Becker and Birdi (2018) identify the digital revolution and a better appreciation of how students learn, as the key drivers for this change. This is well illustrated by the development of the Massive Open Online Courses (MOOCs) and by the significant increase in online degree programmes which impact on how the university estate is utilised (JLL, 2015). While 
recognising that implementation is variable across universities and subject disciplines, the direction of travel is clear and the consequences need to be properly recognised by those designing and investing in new learning environments fit for the next generation.

Newell and Manaf (2017) in a study of universities in Australia found tangible signs of change in response to the digital transformation with education facilities moving from large tiered lecture theatres to smaller tutorial rooms and activity based workplaces. Moreover they noted that the location of the universities is increasingly found in vertical campuses in conventional office buildings in a central business district. To illustrate, 1 Parameter Square in central Sydney is a vertical campus tenanted by Western Sydney University, along with two commercial tenants, and does not have large lecture theatres, but instead modern interactive collaborative spaces. Across the world there are best practice examples of this new generation of university estate ${ }^{4}$ (ibid).

\section{Commercial Property and Corporate Lending}

\section{UK commercial property lending}

While this paper focuses on the financing of major university capital projects, it is important to reflect on the current trends in lending practice across the commercial property sector as a whole. The City University commercial real estate lending survey (2018) demonstrates that the UK property lending is one of the most diversified, sophisticated and specialised global markets. The UK debt market shows significant diversification and specialisation particularly in the last three years. Until $2008,95 \%$ of lending was undertaken by banks whereas by $2017,25 \%$ of secured property lending was undertaken by non-bank lenders including insurance companies and debt funds, such as for example the Aviva Investors UK Commercial Real Estate Senior Debt Fund and the general increased interest by Pension Schemes in in investing in large capital schemes. The survey notes that lenders are making more differentiation between property types. The report also notes that the total debt has been reduced by $36 \%$ from the peak in 2008 due to tightened lending practices the result of regulations following the global financial crisis and the macro-economic recession.

Hutchison et al (2015) examined the challenges of raising infrastructure development finance at a time of capital budget constraints (estimated globally at more than US\$50 trillion dollars over the next 25 years) and found that that the appetite for innovative finance instruments has gained considerable momentum. Delivering private sector finance for such development has prompted many cities in Europe to generate new initiatives involving long-dated bonds where institutions are seeking to match long-term debt to long-term cash flow. Property development debt is viewed as a subsector of the main debt market and is seen as a distinct entity in its own right, an uncorrelated asset class with the possibility of stable, predictable cash flows. The main risk to the cash flow is specific risk relating to the characteristics of the individual project and sector. There are a range of options along the risk curve with some projects viewed as low risk, such as government regulated utilities with built-in $\mathrm{RPI} / \mathrm{CPI}$ uplifts through to high-risk regeneration projects (Adair et al, 2007). Hutchison et al noted that the development bond model has significant appeal at a time when the tightening of the regulatory regime following Basel III and Solvency II has resulted in higher solvency levels and less conventional lending in the market. Their research shows that development bonds would require to have a life span

\footnotetext{
${ }^{4}$ See also for example Royal Melbourne Institute of Technology and the University of Hong Kong.
} 
of 20 years plus with the shift to long-term institutional capital becoming more commonplace, given difficult relationships with banks and restrictions on lending.

\section{Lending practice across the corporate sector: theory and evidence}

It is recognised that universities operate in a unique sector which has different financial characteristics from most corporates. Nevertheless, they must balance their books and be run with financial probity and in that respect lessons can be learnt from considering the borrowing experience from a corporate perspective.

\section{Borrower Reputation}

Diamond (1991) argues that firms build reputation in credit markets through borrowing and repaying private (bank) debt initially. Repetition of this process over time allows firms to build a reputation in credit markets and ultimately borrow at lower cost through publicly traded bonds. The ability to borrow in lower cost public debt markets is a valuable asset that firms must consider in taking on future loans. The loss of such reputation is viewed as a sufficient deterrent to allow high reputation firms to issue debt in unmonitored public markets. Denis and Mihov (2003) and Marshall et al (2016) propose that providers of privately placed debt fill a natural void for low reputation firms. Firm age is frequently used as a measure of reputation in credit markets (see Johnson, 1997; Datta et al., 1999). To mitigate operating and financial risk, low credit quality firms must build up a reputation of being a good borrower by means of bank borrowing. Consequently we would expect that only the highest ranked, more prestigious, larger, and older universities would have access to the public debt markets.

\section{Borrower Size}

Fama (1985) argues that the cost of producing information required for public debt markets is prohibitively high for smaller firms. Large firms naturally produce more information for regulatory purposes, and so find it easier to borrow in public debt markets. Nakamura (1993) argued that small firms are more likely to bank with a single institution that is able to actively monitor cash flows from business accounts. Therefore, larger, more prestigious universities should find it easier to borrow from the public and private bond markets whilst less prestigious universities, who are not as attractive to these lenders, will largely be forced to borrow from commercial banks. Prior empirical literature is almost unanimous in finding that firms who borrow from public sources are larger than those who borrow from private bank sources, see Hadlock and James (2002), Denis and Mihov (2003) and Arena (2011).

\section{Borrower Credit Quality}

Credit quality is correlated with firm age but a more direct measure of credit quality is to look at credit ratings for issuing firms and financial distress measures at the time of issue. It appears that the presence of a credit rating is a good indicator of whether firms have public debt outstanding. Cantillo and Wright (2000) find that few firms have no public debt outstanding if they have a debt rating, and that few firms have public debt outstanding if they do not have a credit rating. Denis and Mihov

\footnotetext{
${ }^{5}$ However, as discussed by Faulkender and Petersen (2006), firms might not have a debt rating not because they do not have access to the public markets, but because they may not want to issue public debt or because they do not want a debt rating.
} 
(2003) observe that high credit quality firms borrow from public sources, that firms with moderate credit quality borrow from banks, and that for firms of a low credit quality, privately placed debt facilitates fulfil their debt financing requirements. More recently, Arena (2011) has reported a different relation between credit quality and privately placed debt, finding that small firms with good credit quality will issue privately placed debt which is again a sign that universities accessing this type of market can absorb the levels of debt that private issuers can lend, but perhaps have insufficient funds to absorb the levels of debt required to enter the public debt markets. The covenant of the major universities are generally perceived to be enormously strong, a point debated in more detail later in Section 5.

\section{Debt Renegotiation}

Berlin and Loeys (1988) and Chemmanur and Fulghieri (1994) argue that private debt is more easily renegotiated in the event of financial distress than publicly traded debt. This arises due to the difficulty in renegotiating across dispersed public bondholders. Private debt involves a smaller number of lenders, consequently private lenders can more readily observe information on the firm's cash flows from investment opportunities in deciding on whether liquidation is optimal (Nakamura (1993) and Yosha (1995)). While on the surface, liquidation may not seem like relevant point in the university sector in the UK as universities have been viewed as being as too big to fail, we will return to discuss this point in more detail when we consider level of borrowings and the covenant strength of the sector overall.

\section{Collateral}

Collateral can be beneficial for firms as lenders perceive borrowers with copious tangible assets as safer borrowers ${ }^{6}$. Denis and Mihov (2003) find that firms are more likely to issue public debt relative to both bank and privately placed debt if they have a higher proportion of fixed assets, but find no distinction between bank and privately placed debt. These studies generally suggest a positive relation from collateral, as measured by the proportion of fixed to total assets, and the likelihood of issuing public debt relative to private debt. The results are less clear when distinguishing between sources of private debt. To the extent that fixed assets suffer from lower information asymmetry and greater certainty over liquidation value, these findings are generally supportive of theories based on efficiency of liquidation. Some universities in the UK have deep property portfolios, many have income producing investments as well as substantial academic buildings, although practice differs across the sector as to whether the fixed assets are shown in the balance sheet at their historic value or at market value.

Firms issuing public debt tend to be larger firms issuing larger amounts, which suffer less from information asymmetry, and consequently require less monitoring. In contrast, issues of private debt, particularly, bank debt, are most attractive for firms issuing smaller volumes of debt finance. Specifically, we look at the choice between European Investment Bank loans and bond financing to fund major capital projects. European Investment Bank loans tend to be for large investment projects and thus differ from standard commercial bank loans where much smaller amounts of finance can be

\footnotetext{
${ }^{6}$ Not only are lenders able to recoup their capital if their debt is secured, and the borrower defaults, but also firms risk their net worth when investing and thus those with high levels of net worth are incentivised to invest efficiently so that they do not lose their net worth (Harris and Raviv (1990)).
} 
borrowed. European Investment Bank loans can therefore be viewed as a hybrid between bilateral bank loans and the public bond markets (see Li, 2005; Marshall et al, 2016).

\section{Market Factors}

Until now we have concentrated on borrower and loan characteristics and how these can affect the choice to issue debt and also the type of debt issued. However it is important to consider how interest rates affect the debt issuance decision. The sole purpose of market timing with regard to debt financing is to take account and advantage of the volatility of interest rates by alternating between long-term and short-term debt, and between different sources of debt, to enjoy the lowest riskadjusted cost of debt.

Graham and Harvey (2001) and Bancel and Mittoo (2004) provide strong evidence of firms employing forward looking market timing strategies when issuing debt. In their surveys of chief financial officers (CFOs), they find that CFOs openly admit to using 'windows of opportunity' and attempting to time their debt issues by issuing when market interest rates are low to lock in low interest rates. In addition, CFOs will also use forward looking market timing strategies if they suspect that market interest rates will decline in the future by issuing short-term debt initially, prior to issuing long-term debt when the market interest rates fall in the future. Given the current historical low interest rates, it is likely that universities will seek to borrow in the debt markets whilst the rates are low in a 'sprint to the finish line' strategy.

\section{Research Design}

The research design involves both a quantitative and qualitative approach to examine the factors that affect both the demand for debt from universities, and the supply of debt to universities from prospective lenders. To examine the factors that affect the demand for debt we extract data from the financial statements of a sample of UK universities and combine this with a survey of university finance directors carried out in the summer of 2018 . We also conducted a number of informal meetings with our home university finance directors as part of our research design. To examine the factors that affect the supply of debt to universities we conducted interviews with three major banks which have considerable experience in lending to the Higher Education sector and an interview with an independent corporate finance adviser who specialises on the Higher Education sector which took place in Spring 2018. We discuss each approach in turn.

\section{Financial Data}

This study is concerned with examining how universities have funded major capital projects such as campus development for teaching, research and office functions rather than day to day borrowing for working capital needs. Therefore, the research focuses on large scale borrowing with medium to long term maturities. As a result, we track only announcements of bonds (both public bonds and privately placed bonds) and European Investment Bank (EIB) loans and disregard standard commercial bank loans for two main reasons. First, over the last decade or so, standard commercial banks have tightened their lending requirements and they are generally lending for shorter maturities. Second, because of this, standard commercial bank loans are typically used for working capital purposes.

As a consequence of resource constraints and relevance it was not possible to collect and record financial data for the whole population of UK universities. In this research, the focus has been on the 
highest ranked universities in the UK because their larger size provides them with access to the capital markets and to European Investment Bank loans, whereas lower ranked universities are somewhat constrained to using standard commercial bank finance as they are unable to get access to these other debt sources due to a variety of reasons such as size, reputational factors and creditworthiness, which act as barriers to accessing the public and private bond markets. This paper analyses the financial characteristics and performance of the top 60 UK universities as stipulated in the 2017 Times Higher Education rankings, providing a sample of 63 universities across the UK ${ }^{7}$. It is acknowledged that as our analysis excludes lower ranked UK universities this introduces a degree of bias in the results and this is discussed further in Section 5.

For each of the 63 universities in our sample we manually search for announcements of public bonds, privately placed bonds and European Investment Bank loans made between 2014 and 2017 using a series of secondary sources, including Thomson Reuters Eikon, the Regulatory News Service, and university annual reports. For each of the 63 universities in our sample we collect staff, student and estates data from Heidi Plus ${ }^{8}$. We supplement this by manually collecting financial and estates data from the footnotes to each university's financial statements for each reporting year between 2013 and $2016^{9}$. We use this sample to analyze the determinants of incremental borrowing decisions between 2014 and 2017 in Section 4 of this paper.

\section{University Finance Director Surveys}

In order to understand the reasoning behind historic financing decisions and to ascertain future demand for lending facilities for capital projects, an online survey was conducted of Finance Directors from all UK universities during the summer of 2018. Prior to the launch of the full survey, a pilot study was conducted among the authors' home universities to check for appropriateness of the survey instrument ${ }^{10}$. The request for participation was circulated by the Executive Director of the British Universities Finance Directors Group (BUFDG) ${ }^{11}$ to all UK universities. 27 completed surveys were returned, representing $15.70 \%$ of the population.

\section{Banking Interviews}

Whilst it is important to examine university financing decisions from the university perspective, i.e. the demand side, it is also important to consider the supply of debt to the Higher Education sector, and how lenders perceive universities as potential borrowers, particularly given the current political uncertainties. Therefore, in the spring of 2018, we conducted face to face interviews with three major banks with considerable experience of lending to the Higher Education sector: Barclays, Santander and HSBC. We also had a face to face interview with an independent corporate finance adviser who specialises on the Higher Education sector to get an overview of supply side options.

\footnotetext{
${ }^{7}$ Five universities were tied at number 59 in the ranking, hence the higher number.

${ }^{8}$ Heidi Plus is a business intelligence service for higher education institutions in the UK. https://www.hesa.ac.uk/services/heidi-plus

${ }^{9}$ We relate the source of borrowing for a firm's marginal financing choice over the subsequent financial year, time $t+1$, to firm characteristics and borrowing history at time $t$.

${ }^{10}$ Following the comments received from our home universities, we edited our questionnaire as appropriate prior to sending out to the BUFDG members.

${ }^{11}$ BUFDG has over 170 members.
} 


\section{Results}

In this section we discuss the results of our quantitative analysis which looks at the debt issuance choice and also our qualitative analysis which examines both the choice to issue debt and the type of debt issued.

\section{(i) Empirical analysis of the choice to issue debt}

Following Arena (2011) and Marshall et al (2016) we examine the incremental financing decisions of universities rather than examining the previous borrowing history of a university by looking at previously issued debt on the university's balance sheet. We choose this approach as it provides a better view of how financing choices relate to both firm and loan characteristics.

Panel A of Table 2 presents the distribution of announcements of issuances of debt financing sources by year and by type of announcement. There are 26 individual announcements of debt, comprising 14 announcements of public or privately placed bonds (53.85\%) and 12 European Investment Bank loans $(46.15 \%)^{12}$. In 2017 there were no issues of European Investment Bank loans which is suggestive of Britain's vote to leave the European Union (BREXIT) having had an impact on the ability of UK universities to borrow from this European source. Panel B of Table 2 presents the distribution of the sample announcements of issuances of debt financing sources by UK region. Over the sample period, universities in England, Wales and Scotland have borrowed from both public and privately placed bond sources and from the European Investment Bank. No university in Northern Ireland has issued a public or privately placed bond.

\section{Insert Table 2 about here}

In Table 3 we present comparisons of university characteristics for our sample of universities. Panel A presents common university characteristics. The average university that issues debt is both older and larger than universities who do not issue debt consistent with the theoretical predictions of Diamond (1991). Russell Group universities are more likely to issue debt than non-Russell Group universities which is suggestive of more prestigious universities having greater access to the debt markets, but universities with a medical school are no more likely to borrow than universities without a medical school. Universities with a greater number of staff and PGT students are also more likely to issue debt. This suggests that these universities have greater accommodation needs and are borrowing to expand their campuses.

\section{Insert Table 3 about here}

In Panel B we look at university finances. Universities which generate higher income from tuition fees and from other sources are more likely to issue debt. This may suggest that from the demand side these institutions have large numbers of students and require more accommodation, both teaching and research, and residential. Whilst on the supply side, lenders may see these institutions as less risky and be more willing to lend to them as they have regular high levels of tuition income. Moreover, universities with higher leverage and who have higher borrowing levels also borrow more. This suggests that universities who have built up a reputation for being creditworthy find it easier to

\footnotetext{
${ }^{12}$ Due to sample size restrictions we do not differentiate between public and privately placed bonds in our incremental analysis.
} 
borrow large amounts, consistent with the theoretical predictions of Diamond $(1984,1991)$. However, the source of existing debt has no impact upon the likelihood to borrow.

Finally, in Panel C we look at university estates data to determine whether existing facilities have an impact on the decision to borrow. Universities with both larger total and non-residential Gross Internal Area (GIA), and larger site areas are more likely to issue debt which suggest that given the competition in the Higher Education sector that these universities are borrowing to expand their campuses so that they can attract and accommodate more fee-paying students. Similarly, universities with a greater number of buildings are also more likely to borrow. This could be symptomatic of universities with larger and, indeed, older, campuses having more refurbishment and rebuilding needs as they need to modernise or replace existing buildings and facilities to again attract more international students and leading researchers, and also to meet carbon neutral targets set by the Government.

In Table 4 we focus on loan characteristics and the differences between bond debt and European Investment Bank loans. The average size of an European Investment Bank loan (f99.01m) is 20\% smaller than that of an average bond issue $(122.90 \mathrm{~m})$. The average EIB loan has a maturity of 27.75 years which is shorter than the average maturity of bonds which is 36.82 years. Whilst Marshall et al (2016) similarly find that the maturity of bank debt is shorter than that of public debt for UK firms, they find that the average maturity of public debt is three times longer than the average bank loan. The difference is likely as result of the reason for borrowing; our sample is concerned with financing EIB loans which are issued for the purpose of large capital projects whilst the sample employed by Marshall et al looks at borrowing by all firms listed on the FTSE350 for various reasons varying from working capital to refinancing existing debt. The average coupon for a bond issue is $3.31 \%{ }^{13}$.

Insert Table 4 around here

We extend our analysis to a multivariate setting in Table 5. We use logit regressions to consider the likelihood of a university issuing debt versus not issuing debt. The value of the dependent variable for sample universities is set to 1 if the university has issued debt (the university has issued either a public or privately placed bond, or an European Investment Bank loan) and zero otherwise. Our results for firm size are consistent with the predictions of theories of debt source based on information asymmetry (see Diamond, 1984, 1991; Fama, 1985). Larger universities are more likely to issue debt than smaller universities to finance major capital projects. We find an important role for prior debt issuance in incremental debt sourcing decisions. This is consistent with the reputation arguments of Diamond (1991), where firms will build a reputation for borrowing and repaying in private (bank) credit markets. This reputation becomes a valuable asset allowing firms to borrow more easily and also in the lower cost public debt markets where the threat of losing this reputation is sufficient to ensure firms do not take on debt they are unable to repay. However, there is no support for information asymmetry and efficiency of renegotiation theories where fixed assets are a measure of collateral and are associated with lower levels of information asymmetry. This is a surprising result which does not easily fit with theory given the high value loans in our sample but the result is perhaps attributable to lenders perceiving universities as being 'too big to fail', and consequently debt recuperation is not a critical concern.

\footnotetext{
${ }^{13}$ Whilst European Investment Bank interest rates can be found in university annual reports, the loans typically have tranches and amounts undrawn which mean that is difficult to calculate the correct interest rate.
} 
We extend our analysis to account for university characteristics such as whether or not a university is a Russell Group university or has a medical school, and staff-student numbers. However, there is only limited evidence that the current condition of the university campus has an impact upon the choice to borrow. As shown in Table 5, universities with greater expenditure on building and repair costs are more likely to issue debt. This suggests that those universities with greater expenditure are issuing debt to upgrade their buildings and so reduce maintenance costs going forwards as well as borrowing to build new accommodation. There is no evidence that the current amount of buildings that a university has or its Gross Internal Area (GIA) impacts on the decision to issue or not.

\section{(ii) Survey of UK University Finance Directors}

27 questionnaires were completed on the on-line survey conducted in the summer of 2018 representing a response rate of 16\%; 17 of the respondents were universities based in England, six from Scotland, three from Wales and one from Northern Ireland. 16 (59\%) of the respondents were in top 60 UK universities as analysed in the 2017 Times Higher Education rankings.

$74 \%$ of the respondents had borrowed to fund major capital projects since 2008 , with nearly all universities embarking on new campus development, with around a half also using the finance raised to upgrade and repair existing buildings. Interestingly over this time period, 35\% borrowed to specifically lock into low interest rates. With regards to the use of the finance, all universities invested in teaching space, $85 \%$ in research buildings, $65 \%$ in sports facilities, $55 \%$ in digital enhancement and $45 \%$ in library facilities. A mix of sources of funding was used with $60 \%$ using bank loans, $40 \%$ EIB loans, $40 \%$ private placement bonds and a further $25 \%$ used additional funding sources including internal resources, government grants and Local Enterprise Partnership (LEP) loans.

For those using bank loans, the ease of renegotiation stood out as a key factor along with the covenant terms and repayment schedule. European Investment Bank loans were preferred for the maturity of the debt and lower interest rates, while privately placed bonds were chosen predominantly because of the fixed interest rates, the covenant terms, the maturity of the debt and the repayment schedule.

Multiple covenant restrictions were imposed by the lenders and these included; debt service cover (85\% of respondents), balance sheet gearing (55\%), operational leverage (35\%), minimum cash balance (15\%) and security cover (10\%). For those with an European Investment Bank loan, 38\% were concerned that the loan will be adversely impacted by the UK's exit from Europe.

$56 \%$ of the respondents were likely to seek new debt financing within the next 5 to 10 years, again mainly for new campus development (89\%), with $47 \%$ also planning to use the finance to upgrade and repair existing buildings. The type of future projects are likely to be similar to the recent past with $93 \%$ planning new teaching space, $80 \%$ research buildings, $47 \%$ digital enhancement, $33 \%$ sport facilities and $20 \%$ on library facilities. A broad range of sources of finance are being considered with $60 \%$ indicating their intention to use privately placed bonds, $27 \%$ bank loans and $13 \%$ public bonds along with a large number who are undecided on the choice of future funding sources.

Respondents were asked whether the REF, TEF, Brexit, pension changes and the recently announced review into university tuition fees had an impact on their university's plans for capital projects. A 
majority thought that all events were considered to be impactful on potential future capital projects with $88 \%$ flagging the review of tuition fees as being of particular concern along with $81 \%$ highlighting the consequences of changes to pension funding.

The fees issue was perceived to be the biggest challenge facing the Higher Education sector with three quotes of particular note:

'The review on tuition fees is a major factor, a freeze or reduction, could have a dramatic effect on the sector. If UK tuition fees are frozen or reduced, it will then be essential that international visas are easily achieved, in order to attract more international students, to compensate for loss of income of UK students'. Respondent 25.

'Income growth can only be achieved through increase in student numbers. Impact of inflation on budgets is not acknowledged in Office for Students funding and tuition fees. General tightening on operating performance restricts cash inflows and weakens the borrowing case with lenders'. Respondent 23.

'Sector fragmentation and stratification will undermine perceptions of the sectors covenant, placing far more reliance on institutional quality'. Respondent 22.

The second part of the survey examined the funding of major residential projects with again a mix of approaches evident, although 63\% used direct financing (on balance sheet), 30\% engaged in joint ventures with private company (off balance sheet) and $7 \%$ leaving it entirely to private sector provision.

Direct financing was the preferred choice mainly because of historic reasons including land ownership and the desire to keep control of the residential space. The dominant source of finance for direct financing was bank loans and to a lesser extent European Investment Bank loans and private placements.

For some universities student residences are not perceived to be core academic activities and in order to protect their balance sheets for academic projects, a joint venture approach (off balance sheet) is chosen for both the supply and maintenance of the residences. Joint venture partners include for example, Liberty Living, Ardmuir, Sanctuary and The Student Housing Company. Other facility management tasks such as car parks, are often wrapped up into the main deal. When asked about future plans for new provision, the joint venture approach was the preferred option. There are a number of joint venture models, but often universities lease the land for a new hall of residence to a special purpose vehicle (SPV) for up to 50 years. The special purpose vehicle raises finance (either an income strip or a bond) against the forecast cashflows and constructs the asset. Over $f 2 \mathrm{bn}$ of student residences have been funded this way, with over $f 600 \mathrm{~m}$ in the period $2017 / 18$. Both the balance sheet and off balance sheet developments enable the universities to have a degree of control over the new residences.

The last 10 years has also witnessed a substantial growth in the 'direct let' student residential market, with halls of residence constructed and managed by private companies independent from the local universities. Seeing a shortfall in supply, private developer/investors have built student residences in cities where there is perceived to be growth in the student population and good rental growth prospects. Moreover, on the back of the perceived resilience of the income stream student housing 
has morphed into an institutionalised real estate investment class. Private student residential investments have attracted substantial interest in recent years with major transactions involving sovereign wealth and overseas pension funds particularly noteworthy. For example, in Feb 2017 in a joint venture agreement with Unite Students, GIC, the Singaporean sovereign wealth fund, bought Aston Student Village in Birmingham for $£ 227 \mathrm{~m}$. In March 2015, the Canada Pension Plan Investment Board (CPPIB) acquired Liberty Living in the UK for $£ 31.1$ bn and later that year purchased Student Castle for $f 330 \mathrm{~m}$. At that point in time the two acquisitions gave CPPIB a combined portfolio of approximately 19,000 beds in 18 UK cities $^{14}$. This market is very active; Savills reported that 40,000 student beds worth $\mathrm{f} 3.9 \mathrm{bn}$ were traded in $2017^{15}$.

\section{iii) Bank interviews}

Five key themes emerged from the semi-structured interviews with the major banks; the shift of long term lending from the banks to the capital markets post the global financial crisis (GFC); the perceived covenant strength of the sector; the importance of the regulatory regime in the different jurisdictions of the UK; the key criteria used by the capital markets to screen loans requests and the financial characteristics of the new lenders to the sector.

\section{The pattern of lending post Global Financial Crisis}

The interviewees all confirmed that the method by which major projects in the Higher Education sector are funded has changed significantly since 2008. Prior to the financial crisis, banks were advancing 30 to 40 year term loans, trying to explicitly match the duration of the loan with the useful life span of the asset. Accompanying this arrangement, banks would request that a percentage of the debt was fixed for a part duration of the loan so that the cost to the borrower would be known in advance, and thus help mitigate any underlying economic shifts or interest rate movements over the tenure of the loan. However, post financial crisis it has become increasingly more difficult to forecast interest rate movements in the long term, and as a result banks have only been willing to lend for 5 to 10 years, as anything beyond this period is too difficult to price and would be too expensive for the borrower. However, banks have been willing to lend for the development phases, say three years, with subsequent longer term funding coming from the capital markets to match the life of the asset.

\section{Covenant strength}

The bankers confirmed that the Higher Education sector remained one of the most attractive sectors to lend to, due to the very low perceived risk of impairment, particularly when compared with the corporate sector. Most lending in the Higher Education sector is on an unsecured basis for the main part, which is different to the corporate sector where lending is secured by means of a security over fixed assets. One justification for this difference was the nature of the specialised design of buildings in education use - a lecture theatre in the middle of a campus offers little security with respect to alternative use in the case of default.

For the top universities, the default risk is perceived to be equivalent to sovereign debt or even better, with for example Moody's rating the University of Cambridge higher than the UK Government (Aaa

\footnotetext{
${ }^{14}$ IPE Real Assets - https://realassets.ipe.com/real-estate/sectors/alternatives/student-housing-a-sleeperemerges/10013136.article (accessed 29/01/19)

${ }^{15}$ Savills - https://www.savills.co.uk/research articles/229130/267737-0 (accessed 29/01/19)
} 
compared with Aa2 $)^{16}$. While such high ratings may conceivably be justified for the top 20 to $30 \mathrm{UK}$ universities which have a global reputation for excellence, default risk is higher and rising among the lower ranked universities. In September 2017, Moody's downgraded seven rated UK universities due to increased concerns that they will not meet their revenue targets ${ }^{17}$. Risk of impairment depends upon a host of factors including the regulatory regime, the strength of the UK economy and the consequent level of government grant, permitted student numbers, the risk of political interference lowering fee levels, government immigration policy changes, the consequences of Brexit on European student numbers, the level and diversification of the internationalisation strategy and planned growth of fee income, research income and the potential loss of EU research grant money and the amount and structure of existing debt. Moreover, while previously it was thought that the funding councils would not allow a university to fail, a different approach may be taken by the Office for Students.

While one lender was supportive of universities investing in their estate to support their strategy for growth, concern was expressed that a large estate may in fact be a burden in the longer term. A helpful distinction was also made between destination universities and campus based universities with the latter having to invest more in their estate than the former, in order to maintain market share in a more competitive based environment. Interestingly it was commented that medical schools are good reputational additions to universities, despite the fact that in reality they are high cost functions.

\section{The Regulatory Regime}

The bankers generally viewed the regulatory regime which surrounds the Higher Education sector, from a risk reduction perspective, positively. For example, the student cap on undergraduate numbers in Scotland was seen as a strength protecting the status quo, whereas the removal of the cap on numbers in England has increased the level of competition potentially polarising the market and introducing more risk. The removal of the student cap has been good for Russell Group universities where student enrolment has increased by approximately 30\% since 2011, but students have been attracted away from lower ranked universities. Both types of university have demanded capital: the top ranked to develop their existing campus to meet the increased demand, while the lower ranked have needed funds to develop their facilities to attract new students. One lender commented that there were growing concerns regarding the sustainability and longevity of some of the lower ranked universities as their increased level of borrowing exposed them to greater risk if tuition fees fall following the current government review or indeed after the next general election. The Office for Students has a regulatory role over funding levels.

Consolidation in the sector was considered by all respondents to be a likely consequence of the increased competition in England and of the likely fall in EU students in Scotland, but that such a scenario was already factored in to their lending decision and from an underwriter's point of view might well be viewed positively, provided any consolidation was orderly.

\section{Lending criteria}

A range of views was expressed on the use of rankings with respect to lending decisions. One lender regarded TEF as a stronger indicator than REF due to the former's more direct influence on

\footnotetext{
${ }^{16}$ www.moodys.com

${ }^{17} \mathrm{https}$ //www.moodys.com/research/Moodys-downgrades-54-UK-sub-sovereign-issuers-and-changesoutlook--PR_372870
} 
undergraduate and postgraduate taught student demand and thus fee income. Another lender did not refer to the rankings directly when making investment decisions unless there had been massive drops in the rankings which required investigation, preferring instead to focus on cash flow generation, balance sheet strength, student enrolment versus targets, trends in UCAS applications, 'leading' subject offerings and capex projections. The third lender identified six key lending criteria: the longevity of the institution, the presence of competitor universities in the locality; whether they were part of the 'squeezed middle' competing against higher ranked universities who have lowered their entry grades; the level of tuition fees, the nature of the diversified income and the likelihood of a 'forced solution' in the future.

\section{The sources of new finance}

In recent years European Investment Bank loans and public and private placements have been the major sources of new capital. European Investment Bank loans essentially take the form of a syndicated loan which combine elements of both traditional bilateral bank lending agreements and the larger value transaction-based lending more commonly associated with raising capital in the public bond markets. However, following the Brexit decision there appears to be no prospect of fresh European Investment Bank lending to the sector. The European Investment Bank loans tended to be for larger investment projects but only covered $50 \%$ of the total project cost ${ }^{18}$. Similar to a traditional bank loan, European Investment Bank loans are amortised over the lending period, with flexibility over drawdown which is perceived to be one of the key benefits of a bank loan over bond finance. The European Investment Bank loans, which have a floating interest rate, were priced at c15 to 50 basis points over LIBOR and thus were cheaper than private placements and public bonds. Despite the favourable pricing and flexibility of the loans, two universities in 2017/18 repaid their European Investment Bank loans, over concerns over covenant flexibility post Brexit.

Private placements and public bonds have interested investors based in both the UK ${ }^{19}$ and US ${ }^{20}$, with lenders normally insurance companies and pension funds. Unlike the European Investment Bank loans, with private placements and public bonds the debt is a fixed interest rate security where universities agree to repay the par value at maturity in addition to coupon payments over the life of the bond. With private placements, the loan size ranges from $f 20 \mathrm{~m}$ to $f 200 \mathrm{~m}$, with cf50m being the modal amount and on pricing the spread would be 75 to 120 basis points over the yield of the gilt of the same maturity or a higher spread if a weaker institution. The tenor ranges from between 15 and 40 years with a bullet repayment.

Public bonds are used for loans over $£ 250 \mathrm{~m}$ and at this size the issue would be included in reference bond indices which encourages a wider market including tracker funds. Public bond issue spreads range from 70 to 80 basis points above the yield of the gilts of the same maturity, although Oxford, Cambridge and Manchester have seen yields lower than this in secondary trading. The tenor ranges from 30 to 40 years with a bullet repayment. There have been 8 listed bonds issuances over the period 2012 to 2017 and their characteristics are listed in Table 6.

\footnotetext{
${ }^{18}$ European Investment Bank loans are similar to syndicated bank loans. Syndicated bank loans

${ }^{19}$ UK based investors have included: Legal and General, Pension Insurance Corporation, Aviva, M\&G investments, Standard Life, Canada Life, Macquarie, BAE Systems

${ }^{20}$ US based investors have included: Barings, MetLife, UNUM, Sun Life Financial, Prudential, Delaware Investments, Northwestern Mutual.
} 


\section{Other sources of financing}

Universities also have access to alternative funding sources such as financial reserves, endowments and donations that could potentially be used to finance capital expenditure projects. However, due to the cost of these capital expenditure projects, financial reserves are normally used as part funding of such projects - such as the 2014 Bangor University European Investment Bank loan - and universities by and large are not holding large cash reserves because they are increasingly spending their cash on new facilities and refurbishment as part of financing deals.

Universities also have access to endowments or philanthropic money accumulated over a number of years which can range considerably between universities. For example, in 2017 the University of Oxford had endowments exceeding $£ 5.5 \mathrm{bn}$ whilst University of Edinburgh had endowments of $£ 392$ million and University of Swansea's endowments were $f 6.1 \mathrm{~m}$. An endowment is usually granted for a specific purpose such as research or scholarship, the endowed asset is kept intact and only the income generated by it is expended. There are various guidelines concerning the use of endowment funds, for example in the US there are guidelines setting out how much a university can spend from their endowment income which for many universities in approximately $5 \%$ of the total asset value. The University of Surrey have used a proportion of endowment funds in the Surrey Research Park which was formed in 1981. The Surrey Research Park is a wholly owned university enterprise unit which is a centre of excellence in technology, science, health and engineering. The university seeks to use the research park to not only raise the profile of the university but to develop an income stream for the university.

Universities can also receive funding the form of donations, but donations are not typically used to finance capital expenditure. In February 2019, the University of Cambridge received a $f 100$ million donaton from David Harding, founder of hedge fund Winton Capital. The university have said that they will use the funds to enhance the student experience such as by providing fully funded PhD scholarships.

Insert Table 6 around here

\section{Mini case studies}

This study is concerned with how universities have funded major capital projects. In this section we include three brief mini case studies: one where an European Investment Bank loan was utilised, one where a public bond was used and one where a privately placed bond was used, to illustrate what universities have done with the funds that they have borrowed.

Bangor University - European Investment Bank Loan

In 2014, Bangor University secured funding of $£ 45 \mathrm{~m}$ from the European Investment Bank as part of their campus redevelopment programme to transform the student experience by investing in redeveloping and modernising their teaching, research and accommodation facilities. As indicated by 
Bangor University's Vice-chancellor at the time of the loan, increasing the attractiveness and student experience at Bangor was paramount when borrowing as the university strived to "upgrade teaching, research and accommodation facilities at Bangor University ....[to] ensure that future generations of students benefit from excellent academic facilities and a world class student experience."

With the money received from the European Investment Bank, which accounted for approximately $50 \%$ of the total campus development plan (the remainder of the funds came from the University's own resources and funding from Welsh European Funding Office (WEFO), and the Welsh Government amongst other sources), Bangor University upgraded halls of residence, improved their sports facilities, invested in new science facilities and renovated the historic main University building.

\section{University of Southampton - Public Bond}

In April 2017, the University of Southampton announced the issue of a 40 year, $£ 300$ million $2.25 \%$ unsecured bond due 2057. The proceeds of the bond issue was used for investment in research, teaching and IT facilities across both campuses to ensure that the university was in the position to continue to provide a world-class teaching and research environment for students and staff.

The issue was particularly successful and with an interest rate of $2.25 \%$, the university enjoyed a record low interest rate for a public bond issued by a UK University illustrating confidence in the UK University market at this time. The bonds were rated Aa2 by credit rating agency Moody's, priced at a spread of $72 \mathrm{bps}$, and the joint book runners in the transaction were Barclays, HSBC and Morgan Stanley.

\section{University of Stirling - Private Placement}

The University of Stirling secured $£ 50$ million funding via a private placement in 2016 . The funds are to be used to refinance existing bank debt at a lower rate of interest, and provide funds for general corporate development including campus development. The placement was well received by the market and comprised a number of both UK and US investors. Whilst the terms and the structure of the deal have not been made publicly available, Stirling's Finance Director noted that the deal was "on very competitive terms", as it was a stable long-term debt arrangement that linked to the institution's assets, and used a mechanism not available from traditional lenders.

Barclay's acted as sole placement agent in the deal and indicated that whilst private placements are not yet widely used by Higher Education Institutions in Scotland to raise debt finance, they are becoming more popular in the education sector because they offer a very stable long term debt arrangement, releasing substantial capital on favourable terms.

\section{Conclusion}

Since the global financial crisis in 2008 , universities have been forced to look at alternative sources of finance due to the unwillingness of banks to lend for periods beyond 5 to 10 years. In recent years, European Investment Bank loans and public and private bond issuances have filled the gap left by the retreating banks during a decade when interest rates have been at a record lows. Universities thirst for capital to undertake major campus development to ensure a competitive advantage and compete globally has been satisfied by pension funds and insurance companies who desire a higher return than is offered in the gilt market, while only taking what they perceive to be a modicum of additional risk. 
The demand for capital has been fuelled in two main ways and both encompass a degree of market timing. First, market timing in terms of attracting students. The partial deregulation of the market in England through the removal of the cap on student numbers, has intensified competition and forced expenditure to satisfy both existing demand and create additional demand through improved facilities, primarily for teaching purposes but also for research facilities particularly in more traditional universities because of the lustre associated with high performing research. It can be argued that fundamentally in England, there has been a so called 'first mover advantage' to universities who have borrowed and invested in their campuses to make them more attractive to fee paying students, particularly premium fee international students.

Second, the demand for capital has also been fuelled by the current low rates of interest and universities have been borrowing, or indeed are in the process of borrowing, to tie in the low rates of interest prior to the expected increase in borrowing rates. While the borrowing covered by our study has taken place during a period of very low interest rates, the annual interest payments and eventual capital repayment are predicated on a certain and growing student base, combined with, as a minimum, an inflation proofed fee level.

However, none of these two key business ingredients - student demand and low interest rates - are entirely in the control of the universities. Brexit has completely destabilised the projected number of EU students likely to enrol in the UK. The 20\% increase in EU students from 2007 to 2016 (Table 1) is likely to decline to some degree post Brexit, particularly in Scotland where the Scottish government currently pays the undergraduate fees of EU nationals studying in Scotland and if this concession is removed alternative university destinations in the rest of the UK or in Europe are able to compete on more even terms. Moreover, UK universities compete in a very competitive global market and recent years have seen the introduction of policy changes by the UK government which have had negative consequences for international student recruitment. In 2012, the UK abandoned the post-study visa that had allowed graduates to stay and work in the country for two years, as the Government led a clampdown on student over-stayers and in 2016 the Conservative Party election manifesto pledged to reduce net migration down to 'tens of thousands', a negative signal for those considering studying in the UK (Guardian, 2018). However in September 2018, UK Universities anxious to promote the UK Higher Education sector as the global first choice, called for return of a time limited visa, and in December 2018 the UK government published a White Paper which outlines changes to visa rules that would extend the length of time students have to stay and find work in the UK after graduating (UK Govt, 2018).

On top of the competitive forces buffeting the sector, universities in England are waiting for the outcome of the Augar Review of student finance due in early 2019. If the recommendation is to reduce the tuition fees that universities can charge undergraduate students, universities will find their main source of income reduced. As a consequence of the combination of possible reductions in student demand post Brexit and lower income from fees, there could be a profound issue whereby universities who wish to borrow to redevelop their campus to make it more attractive to students, are unable to source external debt finance in the future. Moreover those who have secured borrowing in the past may find it difficult to service their debt, as the debt repayments were modelled on the prospect of continuing or enhanced tuition fee income. 
In essence, the covenant strength of the sector has polarised, with those at the top of the standings viewed very favourably, but those in the 'squeezed middle' suffering a drop in their credit ratings. If the sector is hit with persistent unrelenting headwinds then the mettle of the Office for Students will be tested and consolidation maybe a distinct possibility. 


\section{REFERENCES}

Adair, A., Berry, J., Hutchison, N., \& McGreal S. (2007). Attracting institutional investment into regeneration: necessary conditions for effective funding. Journal of Property Research, 24, 221-240

Arena, M. P. (2011). The corporate choice between public debt, bank loans, traditional private debt placements, and 144A debt issues. Review of Quantitative Finance and Accounting, 36, 391-416.

Bancel, F., \& Mittoo, U.R. (2004). The determinants of capital structure choice: A survey of European firms. Financial Management, 33, 103-132.

Becker, R. Birdi, A. (2018). Flipping the classroom: Old Ideas, new technologies, International Review of Economics Education, 29, 1-5.

Beech, D. (2018). Change is coming: how universities can navigate through turbulent political times, Higher Education Policy Institute, Policy Note 7, June, 2018.

Belfield, C., Britton, J., Deardon, L. \& van der Erve, L. (2017). Higher Education funding in England: past, present and options for the future, Institute for Fiscal Studies

HESA (2018) Income and expenditure of HE providers in 2016-17, Higher Education Statistical Authority

Berlin, M., \& Loeys, J. (1988). Bond covenants and delegated monitoring', The Journal of Finance, 43, 397-412.

Cantillo, M. \& Wright, J. (2000). How do firms choose their lenders? An empirical investigation. Review of Financial Studies, 13, 155-189.

Chemmanur, T. J., \& Fulghieri, P. (1994). Reputation, renegotiation, and the choice between bank loans and publicly traded debt. Review of Financial Studies, 7, 673-692.

City University (2018) Commercial Real Estate Lending Survey 2017, Cass Business School, City University and De Montfort University

Cohen, P. (1993). Funding university accommodation. Journal of Property Finance, 4, 49-56.

Cornell University. (2008). The campus master plan

https://masterplan.cornell.edu/doc/CMP PART 1/campus maste plan principles essential featu res.pdf

Curtin University. (2016). Sector leading campus development opportunities, https://properties.curtin.edu.au/local/docs/Greater Curtin Information Memorandum April 2016 . dff

Datta, S., Iskandar-Datta, M., \& Patel, A. (1999). Bank monitoring and the pricing of corporate public debt, Journal of Financial Economics, 51, 435-449.

Denis, D. J. \& Mihov, V. T. (2003). The choice among bank debt, non-bank private debt and public debt: evidence from new corporate borrowings. Journal of Financial Economics, 70, 3-28. 
Diamond, D. W. (1984). Financial intermediation and delegated monitoring. Review of Financial Economics, 51, 393-414.

Diamond, D. W. (1991). Monitoring and reputation: The choice between bank loans and directly placed debt, Journal of Political Economy, 99, 689-721.

European Investment Bank. (2016). Bangor University campus investment and expansion plans gets GBP 45m European Investment Bank backing http://www.eib.org/en/infocentre/press/releases/all/2014/2014-075-gbp-45m-for-bangoruniversity-campus-investment-and-expansion-plans

Fama, E. F. (1985). What's different about banks? Journal of Monetary Economics, 15, 29-39.

Faulkender, M. \& Petersen, M. A. (2006). Does the source of capital affect capital structure? Review of Financial Studies, 19, 45-79.

Goodman, R. (2009). Global recession and universities, Moody's Investors Service.

Graham, J. R., \& Harvey, C. (2001). The theory and practice of corporate finance: Evidence from the field. Journal of Financial Economics, 60, 187-243.

Greenaway, D., \& Haynes, M. (2003). Funding higher education in the UK: the role of fees and loans. The Economic Journal, 113, 150-166.

Guardian (2018). Bring back work visas for overseas graduates, say UK universities, 4 September 2018 ,

Guardian (2018). We won't bail out failing universities, says higher education regulator, 6 November, 2018.

Hadlock, C. J. \& James, C. M. (2002). Do banks provide financial slack? The Journal of Finance, 57, 383419.

Harris, M., \& Raviv, A. (1991). The Theory of capital structure. The Journal of Finance, 46, 297-355.

Harrison, R.T. \& Mason, C.M. (1989). The Role of the Business Expansion Scheme in the United Kingdom. International Journal of Management Science, 17, 2, 147-157.

Hutchison, N., Squires, G., Adair, A., Berry, J., Lo, D., McGreal, S., \& Organ, S. (2015). Financing infrastructure development: Time to unschackle the bonds? Journal of Property Investment \& Finance, 34, 208-224.

James, C. M. (1987). Some evidence on the uniqueness of bank loans. Journal of Financial Economics, 19, 217-235.

Johnson, S. A. (1997). An empirical analysis of the determinants of corporate debt ownership structure. Journal of Financial and Quantitative Analysis, 32, 47-69.

JLL. (2015). Disruption Forces: driving educational workplace change, JLL Corporate Solutions Australia, September 2015. 
$\mathrm{Li}, \mathrm{S}$. (2005). The determinants and implications of bank lending distribution methods: Bilateral versus syndicated lending. Working Paper, University of Rochester

Marshall, A., McCann, L. \& McColgan, P. (2016). The choice of debt source by UK firms. Journal of Business Finance \& Accounting, 43, 729-764.

Nakamura, L.I. (1993) Monitoring loan quality via checking account analysis. Journal of Retail Banking, 14, 16-34.

Newell, G. \& Manaf, Z. (2017). Education as an Asset Class, Western Sydney University.

Parliament.uk (2018)

https://publications.parliament.uk/pa/cm201719/cmselect/cmeduc/343/343.pdf

Peters, M.A. (2017) Technological unemployment: education for the fourth industrial revolution, Educational Philosophy and Theory, 49,1 1-6

Public Finance (2018) https://www.publicfinance.co.uk/news/2018/12/ons-student-loans-changeadds-ps12bn-deficit

The Insider. (2016). University of Stirling raises $550 \mathrm{~m}$ from private security placement https://www.insider.co.uk/news/university-stirling-raises-50m-private-9894579

The Times (2019a) Britons see university fees as poor value, poll reveals, https://www.thetimes.co.uk/article/britons-see-university-fees-as-poor-value-poll-revealsq8vmk7sks

The Times (2019b)

Universities cannot justify as many as three quarters of first-class degrees

https://www.thetimes.co.uk/edition/news/universities-cannot-justify-as-many-as-three-quarters-offirst-class-degrees-2vqsik2f7

The Times (2019c) University debt: credit crunch looms as debt spirals https://www.thetimes.co.uk/article/university-debt-credit-crunch-looms-as-debt-spirals$\underline{2 v m 65 h p q 5}$

UCAS (2018) End of Cycle Report 2018

UK Government. (2018). The UK's future skills-based immigration system. https://www.gov.uk/government/publications/the-uks-future-skills-based-immigration-system

University of Southampton. (2017). University of Southampton today announces the issue of $£ 300$ million $2.25 \%$ bonds due 2057

https://www.southampton.ac.uk/news/2017/04/project-mayflower.page

Universities UK (2018b) International Facts \& Figures,

Universities UK (2018a) Higher education in numbers 
Wales Online, 2019c) Fewer applicants, job losses and financial problems: What's going wrong at Wales' universities?

https://www.walesonline.co.uk/news/education/fewer-applicants-job-losses-financial-15579317

Welsh Government. (2016). The Review of Higher Education Funding and Student Finance Arrangements in Wales, Final Report, September 2016.

Yosha, O. (1995). Information disclosure costs and the choice of financing source. Journal of Financial Intermediation, 4, 3-20. 
Table 1

Nominal Growth in Student Numbers \& Finance 2007/08-2016/17

\begin{tabular}{|c|c|c|c|c|c|c|c|}
\hline & 2007-08 & $2016-17$ & $\begin{array}{c}\% \\
\text { increase }\end{array}$ & England & Wales & Scotland & $\begin{array}{l}\text { Northern } \\
\text { Ireland }\end{array}$ \\
\hline UK HEIS & 166 & 162 & & 133 & 9 & 19 & 5 \\
\hline Non-EU Students & 229,640 & 307,540 & $34 \%$ & & & & \\
\hline EU students & 112,150 & 134,835 & $20 \%$ & & & & \\
\hline UK students & $1,964,310$ & $1,870,000$ & $-5 \%$ & & & & \\
\hline $\begin{array}{l}\text { Income from non-EU } \\
\text { students }(\mathrm{fm})\end{array}$ & 1,800 & 4,683 & $160 \%$ & 3,962 & 153 & 539 & 28 \\
\hline $\begin{array}{l}\text { Non-EU income per HEI } \\
(\mathrm{fm})\end{array}$ & & & & 2,979 & 17 & 28 & 6 \\
\hline Total income (fm) & 23,400 & 34700 & $48 \%$ & & & & \\
\hline Total Expenditure ( $\mathrm{fm}$ ) & 22,900 & 33000 & $44 \%$ & & & & \\
\hline
\end{tabular}




\section{Figure 1}

\section{Comparison of funding for teaching per student}

This figure presents the estimated real terms trend in teaching funding per home student in England, Scotland and Northern Ireland between 2010-11 to 2017-18.

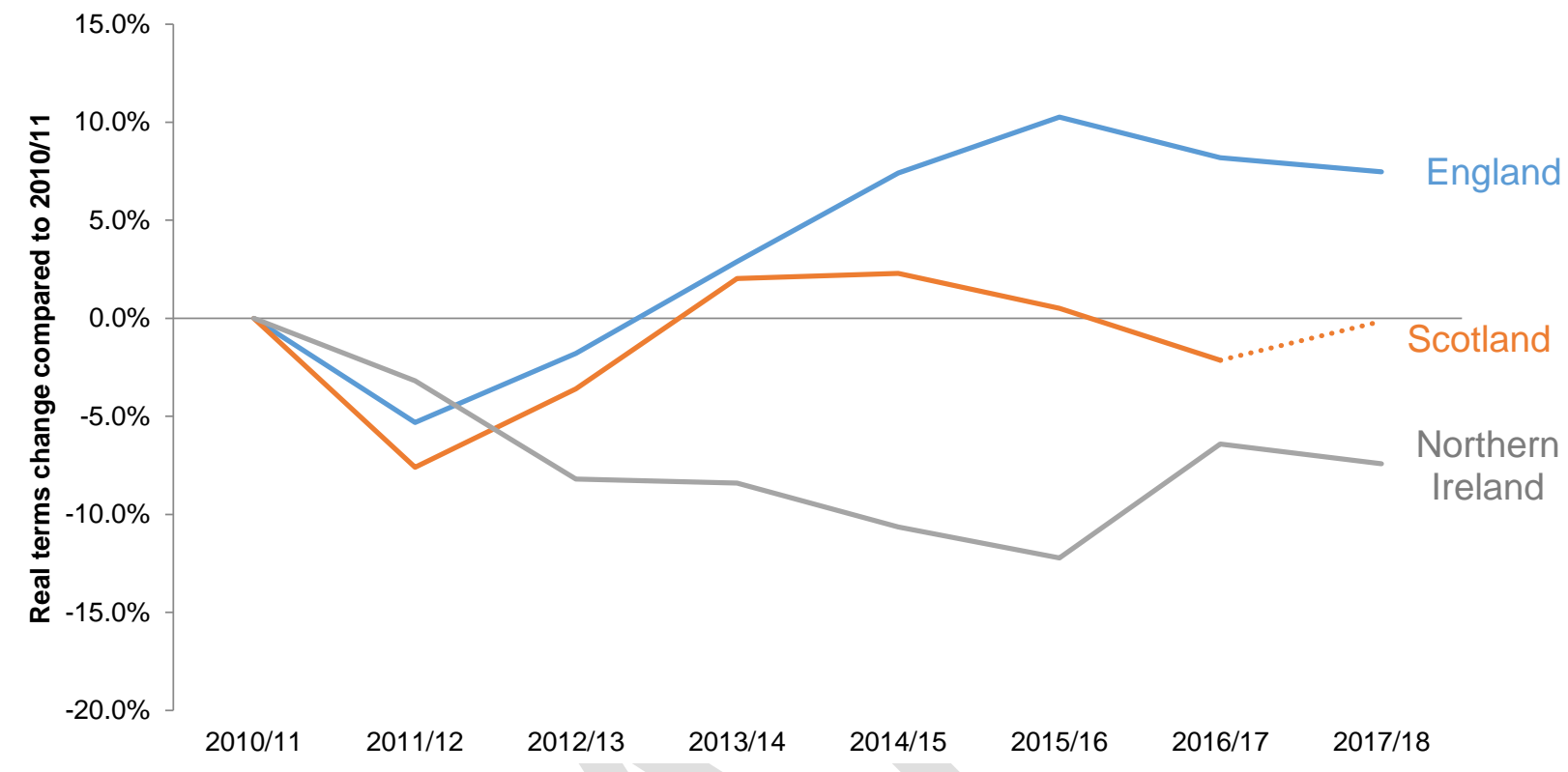

Source UUK 


\section{Table 2}

Distribution of loan announcing universities

The table reports the yearly distribution of announcements of debt offerings for a sample of 63 universities between 2014 and 2017. Results are reported separately for issuance of Bonds and EIB loans. Panel A presents our initial sample of loan announcements across announcing years and source of borrowing. Panel $B$ presents our initial sample of loan announcements across country and source of borrowing.

\begin{tabular}{rrc}
\hline \multicolumn{4}{c}{ Bond } & EIB \\
\hline \multicolumn{2}{l}{ Panel A: Distribution of debt financing sources over time } & \\
\hline 2014 & $0[0.00 \%]$ & $4[33.33 \%]$ \\
2015 & $5[35.71 \%]$ & $3[0.25 \%]$ \\
2016 & $7[50.00 \%]$ & $5[41.67 \%]$ \\
2017 & $2[14.29 \%]$ & $0[0.00 \%]$ \\
Total & $14[100.00 \%]$ & $12[100.00 \%]$ \\
\hline Panel B: Distribution of debt financing sources by country & \\
\hline England & $10[71.43 \%]$ & $7[58.33 \%]$ \\
Scotland & $3[21.43 \%]$ & $1[8.33 \%]$ \\
Wales & $1[7.14 \%]$ & $3[0.25 \%]$ \\
Northern Ireland & $0[0.00 \%]$ & $1[8.33 \%]$ \\
Total & $14[100.00 \%]$ & $12[100.00 \%]$
\end{tabular}


Table 3

\section{Summary Statistics}

This table presents mean [median] comparisons for our sample universities. All characteristics are measured at the year-end prior to the loan announcement. Age is measured as the date of the first establishment of the university. Russell Group is a dummy variable which takes the value of 1 if the university is a member of the Russell Group, and zero otherwise. Post-92 is a dummy variable which takes the value of one for universities which are defined as a Post-92 university, and zero otherwise. Fixed assets ratio is defined as the ratio of plant, property, and equipment to total assets. Investments is defined as the sum of capital expenditures and research and development spending divided by total assets. Earnings volatility is defined as the standard deviation of pretax income minus incomes taxes for the previous three years divided by the average total assets for the period. Return on assets is measured as the ratio of earnings before interest, tax, depreciation and amortization to total assets. Leverage is measured as the book value of total debt divided by the book value of total assets. All debt ratio figures are based on book values. Superscripts are significantly different from the mean [median] or fraction where appropriate for the issuer vs non-issuer categories where $a, b$ and c denote statistical significance at the $1 \%, 5 \%$ and $10 \%$ level respectively. Superscripts are significantly different from the mean [median] or fraction where appropriate for issuers of EIB loans vs issuers of Bonds where $d$, e and $f$ denote statistical significance at the $1 \%, 5 \%$ and $10 \%$ level respectively. The significance of the difference in means is determined using a t-test of means. The significance of the differences in medians is determined in using the Kruskal-Wallis Test, and the significance of the differences in proportions is determined using the Wilcoxon Rank Sum Test. Size is measured as the book value of total assets (fmillions) deflated to 2013 sterling figures using the UK consumer price inflation index.

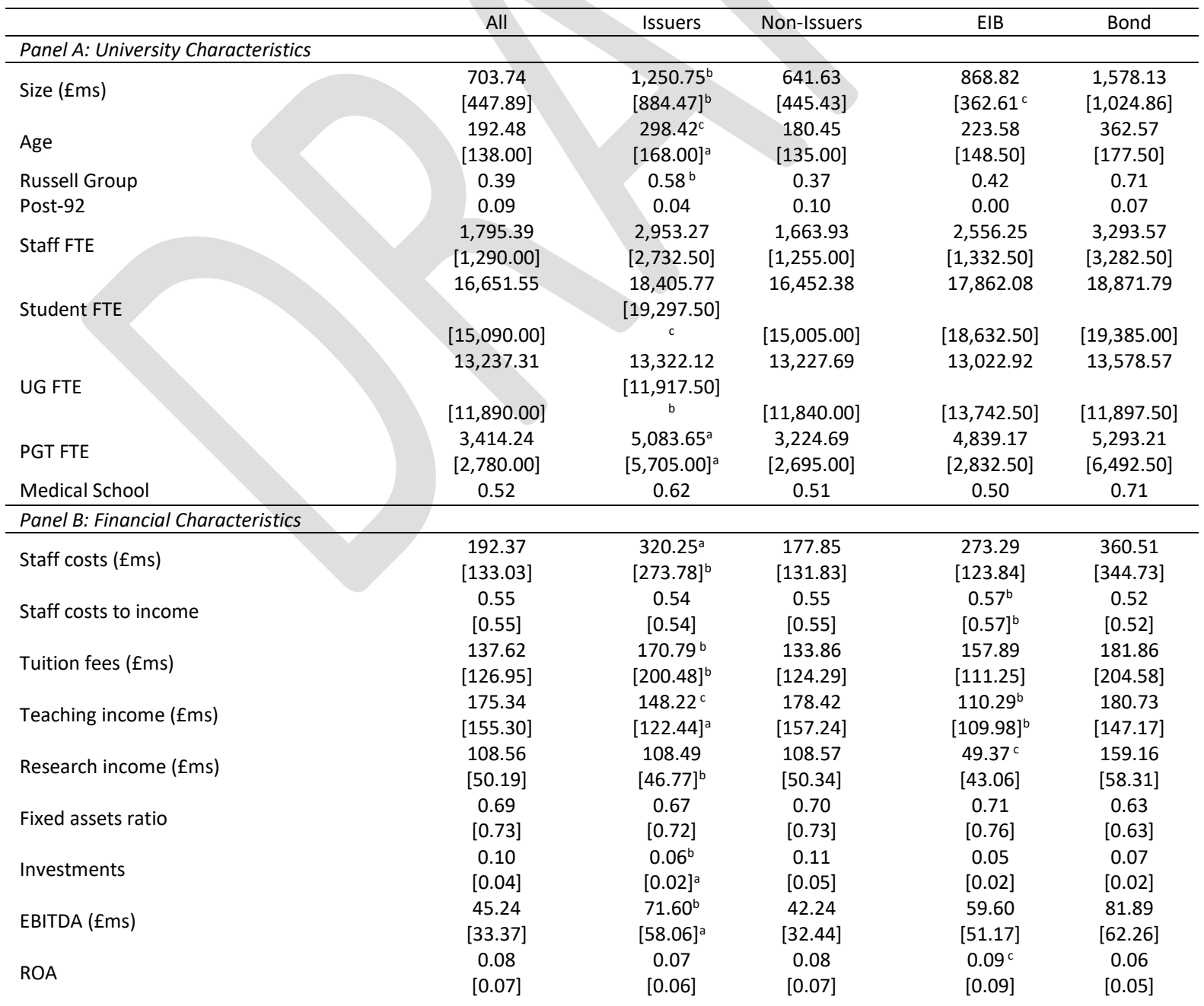




\begin{tabular}{|c|c|c|c|c|c|}
\hline Leverage & $\begin{array}{c}0.15 \\
{[0.15]}\end{array}$ & $\begin{array}{c}0.10^{\mathrm{b}} \\
{[0.08]^{\mathrm{a}}}\end{array}$ & $\begin{array}{c}0.15 \\
{[0.16]}\end{array}$ & $\begin{array}{c}0.08 \\
{[0.04]}\end{array}$ & $\begin{array}{c}0.12 \\
{[0.10]}\end{array}$ \\
\hline Bond debt to total debt & $\begin{array}{c}0.07 \\
{[0.00]}\end{array}$ & $\begin{array}{c}0.08 \\
{[0.00]}\end{array}$ & $\begin{array}{c}0.07 \\
{[0.00]}\end{array}$ & $\begin{array}{c}0.00 \\
{[0.00]}\end{array}$ & $\begin{array}{c}0.14 \\
{[0.00]}\end{array}$ \\
\hline Bank debt to total debt & $\begin{array}{c}0.90 \\
{[1.00]}\end{array}$ & $\begin{array}{c}0.92 \\
{[1.00]}\end{array}$ & $\begin{array}{c}0.90 \\
{[1.00]}\end{array}$ & $\begin{array}{c}1.00 \\
{[1.00]}\end{array}$ & $\begin{array}{c}0.86 \\
{[1.00]}\end{array}$ \\
\hline $\begin{array}{l}\text { Fraction with any public/nbp debt } \\
\text { outstanding }\end{array}$ & 0.12 & 0.08 & 0.13 & 0.00 & 0.14 \\
\hline Fraction with any bank debt outstanding & 0.97 & 1.00 & 0.97 & 1.00 & 1.00 \\
\hline Surplus/deficit (fms) & $\begin{array}{l}16.60 \\
{[6.59]}\end{array}$ & $\begin{array}{c}29.88 \\
{[10.48]}\end{array}$ & $\begin{array}{l}15.09 \\
{[6.43]}\end{array}$ & $\begin{array}{c}12.86 \\
{[11.25]}\end{array}$ & $\begin{array}{l}44.46 \\
{[9.55]}\end{array}$ \\
\hline Total borrowing to income & $\begin{array}{c}0.28 \\
{[0.26]}\end{array}$ & $\begin{array}{c}0.19^{b} \\
{[0.15]^{b}}\end{array}$ & $\begin{array}{c}0.29 \\
{[0.27]}\end{array}$ & $\begin{array}{c}0.13^{\mathrm{c}} \\
{[0.06]^{\mathrm{a}}}\end{array}$ & $\begin{array}{c}0.25 \\
{[0.22]}\end{array}$ \\
\hline \multicolumn{6}{|l|}{ Panel C: Estates Characteristics } \\
\hline Total GIA $\left(\mathrm{m}^{2}\right)$ & $302,234.23$ & $\begin{array}{c}414,507.48 \\
\text { a } \\
{[440,172.9}\end{array}$ & $289,487.04$ & $358,313.04$ & $462,674.15$ \\
\hline & {$[244,570.45]$} & $1]^{\mathrm{a}}$ & {$[238,017.69]$} & {$[233,893.47]$} & {$[469,282.50]$} \\
\hline Residential GIA $\left(\mathrm{m}^{2}\right)$ & $\begin{array}{c}69,541.63 \\
{[71,042.00]}\end{array}$ & $\begin{array}{c}76,368.59 \\
{[71,628.13]} \\
338,138.89\end{array}$ & $\begin{array}{c}68,766.51 \\
{[71,042.00]}\end{array}$ & $\begin{array}{c}73,510.15 \\
{[70,460.00]}\end{array}$ & $\begin{array}{c}78,818.69 \\
{[72,049.13]}\end{array}$ \\
\hline Non-residential GIA (m²) & $229,045.39$ & $\frac{a}{[325,093.8}$ & $216,659.23$ & $284,802.89$ & $383,855.46$ \\
\hline & {$[171,349.60]$} & $5]^{\mathrm{a}}$ & {$[159,564.81]$} & {$[189,419.56]$} & {$[373,369.00]$} \\
\hline Total site area (hectares) & $\begin{array}{l}118.30 \\
{[94.46]}\end{array}$ & $\begin{array}{c}165.11^{c} \\
{[115.86]^{c}}\end{array}$ & $\begin{array}{l}112.89 \\
{[94.46]}\end{array}$ & $\begin{array}{c}198.44 \\
{[123.94]}\end{array}$ & $\begin{array}{c}136.55 \\
{[105.77]}\end{array}$ \\
\hline Total number of buildings & $\begin{array}{c}174.16 \\
{[150.00]}\end{array}$ & $\begin{array}{c}227.19^{b} \\
{[243.00]^{b}}\end{array}$ & $\begin{array}{c}168.01 \\
{[143.00]}\end{array}$ & $\begin{array}{c}221.58 \\
{[208.50]}\end{array}$ & $\begin{array}{c}232.00 \\
{[278.50]}\end{array}$ \\
\hline Non-residential number of buildings & $\begin{array}{c}106.78 \\
{[87.00]}\end{array}$ & $\begin{array}{c}146.73^{b} \\
{[133.50]^{b}}\end{array}$ & $\begin{array}{l}102.16 \\
{[86.00]}\end{array}$ & $\begin{array}{c}131.25 \\
{[133.50]}\end{array}$ & $\begin{array}{c}160.00 \\
{[143.50]}\end{array}$ \\
\hline Residential number of buildings & $\begin{array}{c}67.94 \\
{[38.00]}\end{array}$ & $\begin{array}{c}80.46 \\
{[50.50]}\end{array}$ & $\begin{array}{c}66.48 \\
{[37.00]}\end{array}$ & $\begin{array}{c}90.33 \\
{[50.50]}\end{array}$ & $\begin{array}{c}72.00 \\
{[48.50]}\end{array}$ \\
\hline Building capital expenditure ( $\mathrm{fms}$ ) & $\begin{array}{c}35.08 \\
{[23.22]}\end{array}$ & $\begin{array}{c}31.82 \\
{[19.69]}\end{array}$ & $\begin{array}{c}35.45 \\
{[23.48]}\end{array}$ & $\begin{array}{c}20.44 \\
{[19.69]}\end{array}$ & $\begin{array}{c}41.58 \\
{[19.48]}\end{array}$ \\
\hline
\end{tabular}


Table 4

Characteristics of university borrowing announcements

This table presents selected summary statistics of the characteristics of debt offerings for a sample of 63 universities between 2014 and 2017 . Loan size is the value of the loan deflated to the year 2013. Maturity is measured as the years to maturity for each loan. Interest Rate / Coupon is the coupon rate applicable to the issued bond.

\begin{tabular}{|c|c|c|c|c|c|c|c|c|c|c|}
\hline & \multicolumn{5}{|c|}{ EIB } & \multicolumn{5}{|c|}{ BOND } \\
\hline & Mean & Median & Max & Min & No of Observations & Mean & Median & Max & Min & No of Observations \\
\hline Loan Size ( $\mathrm{fm}$ ) & 99.01 & 86.85 & 200.94 & 7.87 & 12.00 & 122.90 & 96.12 & 290.14 & 19.61 & 14.00 \\
\hline Loan Size/Assets & 0.18 & 0.16 & 0.45 & 0.02 & 12.00 & 0.16 & 0.15 & 0.39 & 0.01 & 14.00 \\
\hline Maturity (years) & 27.75 & 30.00 & 30.00 & 20.00 & 12.00 & 36.82 & 35.43 & 50.74 & 25.37 & 14.00 \\
\hline Interest Rate / Coupon & - & - & - & - & - & 3.309 & 3.31 & 4.105 & 2.26 & 11.00 \\
\hline
\end{tabular}


Table 5

Logit regressions of the choice to issue debt

This table presents the results of logit regressions of the choice to issue debt for a sample of 63 universities between 2014 and 2017. Sample construction and variable definitions are provided in Table 3. Collateral is defined as the ratio of plant, property, and equipment to total assets. All other variables are as outlined in Table 2. P-values are reported in parentheses. $* * *, * *$, and $*$ denote the parameters are significant at the $1 \%, 5 \%$, and $10 \%$ levels respectively.

\begin{tabular}{|c|c|c|c|c|c|}
\hline & (1) & $(2)$ & (3) & (4) & (5) \\
\hline \multirow[t]{2}{*}{ Size } & $0.0005^{* *}$ & $0.0005^{* *}$ & -0.0003 & $0.0005^{* *}$ & $0.0004 *$ \\
\hline & $(0.024)$ & $(0.034)$ & $(0.437)$ & $(0.036)$ & $(0.090)$ \\
\hline \multirow[t]{2}{*}{ Age } & 0.0005 & 0.0007 & 0.0005 & 0.0005 & 0.0003 \\
\hline & $(0.486)$ & (0.399) & $(0.494)$ & $(0.493)$ & $(0.634)$ \\
\hline \multirow[t]{2}{*}{ Collateral } & 0.6848 & 0.7392 & 0.8363 & 0.5076 & 0.2462 \\
\hline & $(0.481)$ & $(0.446)$ & $(0.421)$ & $(0.643)$ & $(0.840)$ \\
\hline \multirow[t]{2}{*}{ Total debt } & $-0.0037 * *$ & $-0.0036^{*}$ & -0.0029 & $-0.0036^{*}$ & $-0.0042 * *$ \\
\hline & $(0.047)$ & $(0.063)$ & $(0.102)$ & $(0.064)$ & $(0.023)$ \\
\hline \multirow[t]{2}{*}{ ROA } & -0.4079 & -0.3972 & -0.07100 & -0.4985 & -0.1343 \\
\hline & $(0.814)$ & $(0.813)$ & $(0.969)$ & $(0.776)$ & $(0.945)$ \\
\hline \multirow[t]{2}{*}{ Russell Group } & & 0.06157 & & & \\
\hline & & $(0.818)$ & & & \\
\hline \multirow[t]{2}{*}{ Medical School } & & -0.3317 & & & \\
\hline & & & -0.0004 & & \\
\hline Student FTE & & & $\begin{array}{l}(0.461) \\
-0.0000\end{array}$ & & \\
\hline Staff Costs & & & $\begin{array}{l}(0.114) \\
0.0000\end{array}$ & & \\
\hline \multirow[t]{2}{*}{ Teaching Income } & & & & $0.7000 * *$ & \\
\hline & & & & $(0.029)$ & \\
\hline \multirow[t]{2}{*}{ Research Income } & & & & 0.1558 & \\
\hline & & & & (0.3/8) & \\
\hline \multirow{3}{*}{ Total number of buildings } & & & & & $\begin{array}{l}0.2808 \\
(0.309)\end{array}$ \\
\hline & & & & & 0.0000 \\
\hline & & & & & $(0.984)$ \\
\hline \multirow[t]{2}{*}{ Repair and maintenance costs } & & & & & $0.0000 *$ \\
\hline & & & & & $(0.051)$ \\
\hline \multirow[t]{2}{*}{ Intercept } & $-1.9925 * *$ & $-1.9567 * *$ & $-2.1337 * *$ & $8.4948^{*}$ & -4.8022 \\
\hline & $(0.012)$ & $(0.011)$ & (0.017) & $(0.057)$ & $(0.108)$ \\
\hline Number of Observations & 246 & 246 & 246 & 246 & 241 \\
\hline R-Square & 0.09984 & 0.1081 & 0.1526 & 0.1376 & 0.1267 \\
\hline
\end{tabular}


Table 6

University public bond issuance: 2012-2017

This table presents an overview of public bond issuance and the characteristics of the issued bonds by UK universities between 2012 and 2017

\begin{tabular}{|c|c|c|c|c|c|c|c|c|}
\hline $\begin{array}{l}\text { University Public } \\
\text { Bonds }\end{array}$ & $\begin{array}{l}\text { De Montfort } \\
\text { University }\end{array}$ & $\begin{array}{c}\text { University } \\
\text { of } \\
\text { Cambridge }\end{array}$ & $\begin{array}{c}\text { University } \\
\text { of } \\
\text { Manchester }\end{array}$ & $\begin{array}{l}\text { University of } \\
\text { Northampton } \\
\text { (IUK) }\end{array}$ & $\begin{array}{c}\text { University } \\
\text { of } \\
\text { Liverpool }\end{array}$ & $\begin{array}{l}\text { University } \\
\text { of Cardiff }\end{array}$ & $\begin{array}{l}\text { University } \\
\text { of Leeds }\end{array}$ & $\begin{array}{l}\text { University of } \\
\text { Southampton }\end{array}$ \\
\hline Size & $f 110 \mathrm{~m}$ & $£ 350 \mathrm{~m}$ & f300m & $f 232 m$ & $\mathrm{f} 250 \mathrm{~m}$ & $f 300 m$ & $f 250 \mathrm{~m}$ & $f 300 m$ \\
\hline Date & Jul-12 & Oct-12 & Jul-13 & Nov-14 & Jun-15 & Jan-16 & Feb-16 & Apr-17 \\
\hline Term (years) & 30 & 40 & 40 & 40 & 40 & 39 & 34 & 40 \\
\hline Spread over Gilt (bps) & 276 & 59 & 80 & 43 & 80 & 85 & 100 & 72 \\
\hline Yield/Coupon & $5.38 \%$ & $3.75 \%$ & $4.25 \%$ & $3.30 \%$ & $3.38 \%$ & $3.00 \%$ & $3.13 \%$ & $2.25 \%$ \\
\hline Rating & $\begin{array}{c}\text { Aa1 at issue, } \\
\text { later } \\
\text { downgraded } \\
\text { to } A a 2\end{array}$ & Aaa & Aa1 & $\begin{array}{l}\text { Unrated } \\
\text { (guaranteed } \\
\text { by HM } \\
\text { Treasury) }\end{array}$ & $\mathrm{Aa} 2$ & $\mathrm{Aa} 2$ & $\mathrm{Aa} 2$ & $\mathrm{Aa} 2$ \\
\hline Security & Unsecured & Unsecured & Unsecured & Unsecured & Unsecured & Unsecured & Unsecured & Unsecured \\
\hline
\end{tabular}

Source: QMPF 


\section{Appendix 1}

Top 60 UK universities

This appendix lists the top 60 UK universities as ranked by THE 2017

\begin{tabular}{|c|c|}
\hline THE 2017 rank & $\underline{\text { University }}$ \\
\hline 1 & University of Oxford \\
\hline 2 & University of Cambridge \\
\hline 3 & Imperial College London \\
\hline 4 & University College London \\
\hline 5 & London School of Economics and Political Science \\
\hline 6 & University of Edinburgh \\
\hline 7 & King's College London \\
\hline 8 & University of Manchester \\
\hline 9 & University of Bristol \\
\hline 10 & University of Warwick \\
\hline 11 & University of Glasgow \\
\hline 12 & Durham University \\
\hline 13 & University of Sheffield \\
\hline 14 & University of St Andrews \\
\hline 15 & Queen Mary University of London \\
\hline 16 & University of Southampton \\
\hline 17 & University of Exeter \\
\hline 18 & University of York \\
\hline 19 & University of Birmingham \\
\hline 20 & University of Leeds \\
\hline 21 & Lancaster University \\
\hline 22 & University of Nottingham \\
\hline 23 & University of Sussex \\
\hline 24 & University of Liverpool \\
\hline 25 & University of East Anglia \\
\hline 26 & University of Leicester \\
\hline 27 & Royal Holloway, University of London \\
\hline 28 & University of Dundee \\
\hline 29 & Cardiff University \\
\hline 30 & University of Aberdeen \\
\hline 31 & Newcastle University \\
\hline 32 & University of Reading \\
\hline 33 & Birkbeck, University of London \\
\hline 33 & Queen's University Belfast \\
\hline 33 & St George's, University of London \\
\hline 36 & University of Bath \\
\hline 36 & University of Surrey \\
\hline 38 & Aberystwyth University \\
\hline 38 & Anglia Ruskin University \\
\hline 38 & Bangor University \\
\hline 38 & Brunel University London \\
\hline 38 & University of Essex \\
\hline
\end{tabular}




\begin{tabular}{|l|l|}
\hline 38 & Goldsmiths, University of London \\
\hline 38 & University of Kent \\
\hline 38 & Loughborough University \\
\hline 38 & Royal Veterinary College \\
\hline 38 & University of Stirling \\
\hline 38 & Swansea University \\
\hline 49 & Aston University \\
\hline 49 & City, University of London \\
\hline 49 & Plymouth University \\
\hline 52 & Heriot-Watt University \\
\hline 52 & Keele University \\
\hline 52 & The Open University \\
\hline 52 & Oxford Brookes University \\
\hline 52 & University of Portsmouth \\
\hline 52 & Soas, University of London \\
\hline 52 & University of Strathclyde \\
\hline 59 & University of Hertfordshire \\
\hline 59 & University of Hull \\
\hline 59 & Liverpool John Moores University \\
\hline 59 & Middlesex University \\
\hline 59 & Ulster University \\
\hline & \\
\hline
\end{tabular}

